\title{
Influencing Factors of Internet Usage among Women Entrepreneurs
}

\author{
Muhaini I. \\ Public Service Department (JPA), Putrajaya, Malaysia \\ Azhar Ahmad \\ Universiti Kebangsaan Malaysia (UKM)
}

\begin{abstract}
Malaysian women are recognised to play a major role in the growth of Small and Medium Enterprises (SMEs). Previous studies show that ICT is an important factor influencing the growth of women entrepreneurs in Malaysia. This study aims to analyse the Internet skills among women entrepreneurs and the influencing factors encouraging them to use Internet in their business activities. A survey was conducted on 51 women entrepreneurs in Putrajaya, Malaysia. The study showed positive relationship between Internet skills and influencing factors on Internet usage in business. However, only factors "ease of use" and "social influence" have significant relationships toward the intention of Internet usage among the entrepreneurs. Thus, Internet usage among the entrepreneurs are inflluenced by the ease of use of technology and social factors. Social influence from media, family members and fellow entrepreneurs have pushed these business women to use Internet as a new medium to improve their business activities.
\end{abstract}

Keywords; Women entrepreneurs, Internet skills, Ease of use and Social influence

\section{INTRODUCTION}

Today, Internet has changed our ways of living either personally or professionally. Internet is the platform for entrepreneurs to conduct electronic transaction which is also known as ecommerce. The extension of Internet has given access and opportunity to do business with the capability of technology. Malaysian entrepreneurs are no exception in implementing and using Internet to improve the communication and information technology for their businesses.

Emasria (2006), explained that e-commerce is commonly linked to bigger market place that involves direct transactions with the customers, business to customer (B2C) and trades between companies, business to business (B2B). In 2012, the Ministry of Communication and Cultural Information has introduced the 1Malaysia Internet Broad Band as an effort to encourage Malaysian to use Internet. Government incentive such as tax deduction towards ecommerce activities has given new hope for companies especially local entrepreneurs.

Knowledge in using Internet and latest technology has become one important factor for entrepreneurs to successfully compete in business today. Besides business transactions, Internet provides channel for various parties to share information and technology. Factors that influence business people to use Internet need to be identified in order to help them to choose the best medium to their business activities. Entrepreneurs need to know the benefits that they will get when they are in fluent in using the Internet. They should realize that the Internet should be recognized as an important media alternative in view of its preference and effectiveness of advertising execution (Yoon, S-J. \& Kim, J. H., 2001). Using Internet, challenges and problems in their business can be detected earlier and solved more effectively. 


\section{Problem Statement}

The study analyses the level of Internet skills among the entrepreneurs and the factors that influence the entrepreneurs in using Internet in their business. The aspects of the study include;

- What is the skill level of the entrepreneurs in Internet usage?

- What are the factors that encourage entrepreneurs in subscribing Internet?

- What are the relationship between the influencing factors and Internet usage?

The purpose of the study is to assess the Internet knowledge of women entreprenuers and the factors that attract them to do business online. The study aims to analyse the relationships between the factors and the Internet usage among women entreprenuers. Using Internet has become important in conducting business during this global environment. In addition, this study is consistent with the government intention of ensuring business people, contractors and suppliers to use Internet in their daily routine which enable the to compete effectively.

\section{LITERATURE REVIEW}

Entrepreneurs will create new ideas or develop new products and also market them. On the other hand, businessmen only conduct their transactions with customers and seldom sell products that are from their own creation. Zafir, Hizam and Fazilah (2013) identified entreprenuers as individuals who create new products or services. Entreprenuers are also those who can assess and take opportunities from the changes in economy, provide financial needs and take risks.

\section{Women Entrepreneurs}

Entrepreneurship is of critical importance to women because it provides a means to becoming self-sufficient, in charge of one's own career path, and as a way to rise above the "glass ceiling" of the corporate world. There is a correlation between female entrepreneurship and economic growth (Minniti,2009). In the U.S. the numeber of women-owned companies have grown 68\% since 2007, compared with $47 \%$ for all businesses (The Atlantic, 2015. Adult females provide an available group of potential entrepreneurs to improve economies in all areas (Deamer $\&$ Earl, 2004).

Women are motivated to start a business for different reasons than their male counterparts (Hornaday,1982); these reasons include self-realization, status, financial success, autonomy, and personal development and are heavily influenced by the early socialization experiences of women as they grow up (Marshall \& Oliver, 2005). Gender role socialization implies that traditional attitudes about gender roles and the accompanying stereotypes had a tremendous influence on women's career choices and occupational self efficacy during the early years of the 20th century through the late 1970's (Klein \& Cook,2005).

Malaysian women entrepreneurs are increasingly recognised to play an important role to the unprecedented rate of growth of the Small and Medium Enterprises (SMEs) and indirectly to the Malaysian economy. In 2003, there were $1,122,000$ or $36.8 \%$ of women enterpreneurs from the total employment in SMEs (Nurwahida \& Abdul Manaf, 2011). According to Hamisah (2002), 445 of Malaysian women surveyed professed desire for self-employment. Women participation in economic activity has become a growing importance to the development of Malaysia (Abdul Jumaat \& Jasmani, 2012). Women are not compelled to do their duty at home but majority of them has participated in business. Their courage and high commitment in business has shown a tremendous success in contributing to the nation success (Norudin, Suzanna \& Siti, 2008). 


\section{Internet Skills}

Effective usage of Internet usage has a strong link on their previous experience in using the Internet. Skills of using Internet is referred to the ability to organize, implement and complete tasks related to the Internet successfully (Eastin \& LaRose, 2000). Van Gelderen, (2007) noted that entrepreneurial skills are the ability of translating one's behaviours or actions as an entreprenur. These skills include the ability to start new business, make decisions, identify opportunities, manage time, communicate well and solve poblems creatively. Since Internet enables us to work more productively and efficiently, ability in using Internet is another important skill for the entrepreneurs.

Couple with the need of women enterpreneurs to serve the women market, businesses need more women in order to capture the full benefit of diverse thinking and problem solving of making decisions and managing strategies based on their expectations on business growth. However, there are some significant barriers remain for women establishing and growing businesses. As shown in Fig 1, these barriers can be summarised to four elements, i.e. financial and capital assistance; network; education, training and counseling; and usage of ICT, which impact on the growth of women entrepreneurs in the development of SMEs in Malaysia.

Figure 1: Factors on Growth of Women Entrepreneurs

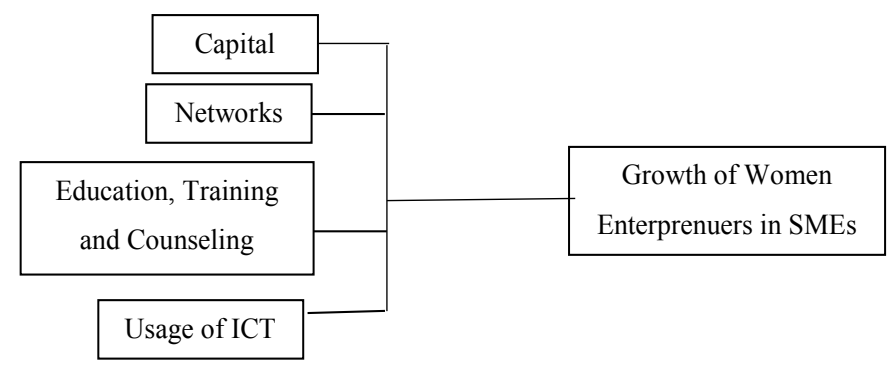

\section{Source; Wendy, T. \& Siong-Choy, C. (2008)}

The use of ICT is crucial and arguably unique in allowing small businesses and their entrepreneurial owners to sharpen their strategies in order to achieve success (Martin \& Wright, 2005). The wide-reach of technology provides business women with greater access to the market, networking opportunities, and greater promotional capabilities which will undoubtedly augment the competitive advantages for their businesses. There exists a "digital gap" between urban and rural women even though the government and NGOs have jointly organized many training programmes and seminars on ICT.

This resulted in the development of a research framework which points out that financial assistance, networking, training, education and counseling, and usage of ICT are critical factors to the success of women entrepreneurs in the SMEs.

\section{Factors Influencing the Usage of Internet Trust}

A study done by Jarvenpaa, Tractinsky and Vitale (2000) found that trust is important to issues related to risks via electronic exchanges. This shows that trust is the main factor given by consumers when using any applications in a website. In addition, Cho, Kwon and Lee (2007) noticed that trust is an important and complicated aspect in an environment such as ecommerce as compared to conventional business transaction. 
Trust has also becoming a basic factor in any e-purchasing website (Lim, Lim, \& Heinrichs, 2008). High acceptance of trust in a particular website will improve the confidence of the customers. Therefore, factor of trust is the determint factor whether a customer will decide to use the application and make a purchase or not (Emasria. 2006).

\section{Usefulness}

Davis, Bagozzi and Warshaw (1989) used two variables such as usefulness (very important and useful) and ease of use on their study of acceptance of new techology. From the study, they found that factor of usefulness had a strong significant level on the usage of the new technology such as e-mail system.

Meanwhile, Lee (2009) identified that the variable of usefulness had shown positive relationship that could influence the usage of Internet banking in Taiwan. Hence, usefulness will influence the customer intention of using new technology.

\section{Ease of Use}

Research have shown that ease of use factor can effect the intention of an individual to buy online or through offline methods (Kloping \& McKiney, 2004). Users will analyse and try any application by ensuring that it is easy to use and eventually effect the customers' purchase decision. Ease of use is another important factor that can influence the customers to purchase electronically (McCloskey, 2004). For enterpreneurs, ease of use of electronic equipments is important in order for them to operate their business electronically.

\section{Social Influence}

Social factor also influences the intention of the entrepreneurs to use Internet in their business activity. Fan and colleagues (2005) discovered that users like to give proposals and ideas to others if they are satisfied with the service rendered. In general, they will inform and recommend their close friends to try and use the system available.

Social influnce certainly has a direct influence on the acceptance of e-commerce system among the entrepreneurs. Previous study had confirmed the significant effect of social influence on the application of e-commercein doing business (Wei, et al., 2009). Consequently, social media such as Facebook and Twitter have become major websites for people to do business electronically (Normah, et al., 2013).

\section{Intention of Internet Usage}

Internet has provided various facilities to society including e-mail, websites, internet relay chat (IRC), telnet and others. Society should be wise enough to choose the appropriate application for their needs. Internet has become one opf the main platforms of business that facilitates bsuiness transactions and e-commerce. Business has increased the Internet usage because several ways; marketing, selling products and accepting payment electronically. In addition, companies are able to create corporate network through "intranet". Online business have proven to bring in lucrative incomes to new entrepreneurs (Anon, 2008).

Intention to use technology is equally important not only to encourage new technology but also to encourage people to use technology continuously without any hesitation (Man \& Waiman, 2001). Based on previous studies, the study framework is as follows. 
Figure 2: Study Framework

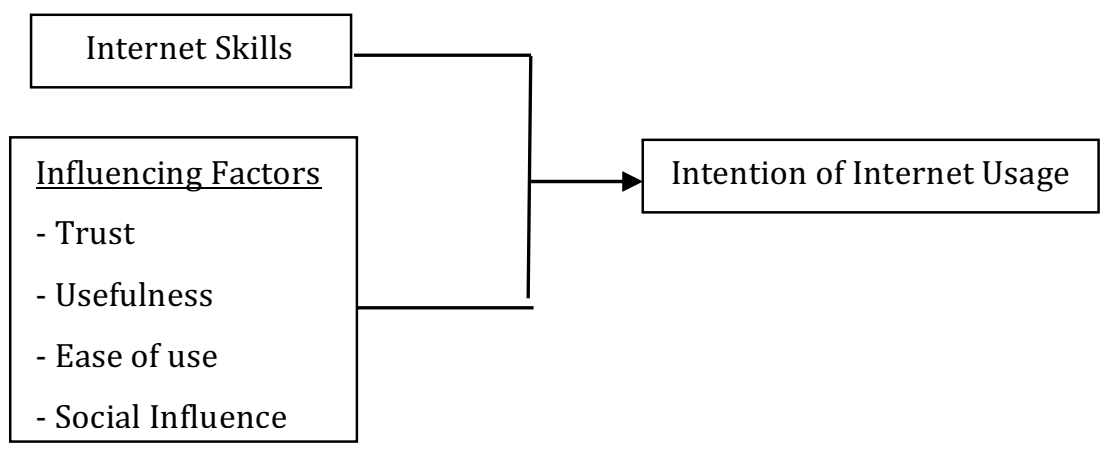

METHODOLOGY

\section{Research Instrument}

The study is descriptive in nature and questionnaire is used as the instrument of data collection. The instrument is divided into four (4) sections. Section A begins with information related to the demographic profile of respondents. Section B seeks information on Internet skills and Section B has questions related to the factors influencing the use of Internet in business. Finally, Section D has questions on the intention on Internet use among entrepreneurs. The statements were adopted from Micheal Ringgit (2008) and Sara Naimi Baraghami (2007).

\section{Sampling}

Respondents of the study were women entrepreneurs and convenience sampling method was used in the study. The questionnares were distributed to 70 companies that are located in Putrajaya, Malaysia. The collected data was then analysed using SPSS for Window version 22.0.

\section{Respondents' Profiles}

\section{ANALYSIS}

Overall, 51 questionnares were collected for the study, i.e $72.9 \%$ response rate. Table 1 shows the distribution of the respondents according to age, education level, marital status and business type. In terms of age, most of them (84.3\%) are between 31 to 40 years old. This means these women entrepreneurs are considered to be young and lower middle age groups. In education, majority of them (64.7\%) have secondary education. However, 17 (33.3\%) of them are university graduates.

From the data analysed, most of the respondents are married (82.3\%) and three of them (5.9\%) are single mother. In terms of business ownership, most of the businesses (90.2\%) in Putrajaya are owned by the women entrepreneurs themselves. Only 5 outlets (9.8\%) are managed through partnership. 
Table 1: Profiles of Respondents ( $\mathrm{N}=51$ )

\begin{tabular}{lclc}
\hline \multicolumn{1}{c}{ Age } & Freq & \multicolumn{1}{c}{ Educ Level } & Freq (\%) \\
\hline Less 30 yrs old & $2(3.9 \%)$ & Lower Secondary & $1(2.0 \%)$ \\
$31-35$ yrs & $21(41.2 \%)$ & Up. Second \& Diploma & $33(64.7 \%)$ \\
$36-40$ yrs & $22(43.1 \%)$ & Degree & $15(29.4 \%)$ \\
$41-45$ yrs & $5(9.8 \%)$ & Post Graduate & $2(3.9 \%)$ \\
Above 46 yrs & $1(2.0 \%)$ & & \\
\multicolumn{1}{c}{ Marital Status } & Freq & \multicolumn{1}{c}{ Business Type } & Freq \\
\hline Single & $6(11.8 \%)$ & Sole ownership & $46(90.2 \%)$ \\
Married & $42(82.3 \%)$ & Partnership & $5(9.8 \%)$ \\
Single mother & $3(5.9 \%)$ & & \\
& & & \\
\hline
\end{tabular}

\section{Descriptive Analysis}

For reliability, the values of Cronbach Alpha must be above 0.5 (Sekaran, 2003). In this study, the Cronbach Alpha ranges from 0.7 to 0.94 . Hence, the study achieved between high and very high reliability values.

Mean values are used to describe the perceptions of the respondents on the studied variables. Based on the 5-Likert scale of 1 to 5, the values are divided into three; low, moderate and high. Table 2 shows the mean values of each variable. The results showed that each variable has different level of means. For instance, "trust" has the lowest mean value of 2.64 depicting moderate level, while "intention of internet usage" has the highest value of 4.25. Both "intention of internet usage" and "usefulness" showed high level and the other four varibles showed moderate level.

Table 2: Descriptive Analysis of Respondents

\begin{tabular}{lccc}
\hline & Mean & Std Deviation & Level \\
\hline Internet Skills & 2.98 & 1.21 & Moderate \\
Trust & 2.64 & 0.80 & Moderate \\
Usefulness & 3.86 & 0.57 & High \\
Ease of Use & 2.98 & 1.14 & Moderate \\
Social Influence & 3.05 & 1.18 & Moderate \\
Intention of Internet Usage & 4.25 & 0.84 & High \\
& & & \\
\hline
\end{tabular}

\section{Correlation}

Correlation tests were done to investigate the relationship between independent and dependent variables. Davies scale (1971) was used to assess the strength of the relationships ranging from low $(0.01-0.1)$ to very strong ( above 0.70$)$.

\section{Relationships among Internet Skills, Influencing Factors and Intention of Internet Usage}

The results of the corelations between the variables are shown in Table 3. The study showed positive relationship between Internet Skills with Intention of Internet Usage. In terms of strength, the relationship is low with $r$ value of 0.241 with no significant relationship between the variables $(\mathrm{p}=0.066)$.

There are positive relationships between the Influencing Factors and Intention of Internet Usage. Overall, the strength of the relationship is at low level $(r=0.187)$. Specifically, factors such as "ease of use" and "social influence" showed significant relationship with the Intention of Internet Usage. This means the women enterpreneurs tend to use Internet in doing business when they are influenced by others especially fellow entrepreneurs and if the process is easy to use. Meanwhile, factors "trust" and "usefulness" have low relationships and not significant to 
Internet usage. The women entrepreneurs are not confidence of using Internet because of security reasons. Also, with very low strength $(r=0.047)$, some of the enterpreneurs did not consider factor of "usefulness" in Internet when running their business. Hence, they still use the traditional way of doing business transactions.

Table 3: Correlations between Independent Variables and Intention of Internet Usage

\begin{tabular}{lccc}
\hline & $\begin{array}{c}\text { Pearson Correlation } \\
\text { (r) }\end{array}$ & Sig. (2-tailed) & Level \\
\hline Internet Skills & 0.241 & 0.066 & Low \\
& & & \\
Influencing Factors & & & \\
$-\quad$ Trust & 0.206 & 0.117 & Low \\
$-\quad$ Usefulness & 0.047 & 0.727 & Very Low \\
$-\quad$ Ease of Use & $0.488^{* *}$ & 0.000 & Moderate \\
$-\quad$ Social Influence & $0.507^{* *}$ & 0.000 & Strong \\
\hline
\end{tabular}

** Significant at 0.01 level (2-tailed)

* Significant at 0.05 level (2-tailed)

\section{CONCLUSIONS AND DISCUSSION}

The study showed positive relationship between both independent and dependent variables. However, only "ease of use" and "social influence" factors have significant relationships toward the intention of Internet usage among the women entrepreneurs. Consequently, Internet usage among the entrepreneurs are inflluenced by the ease of use of technology and social factors. Social influence from media, family members and fellow entrepreneurs have pushed the enterpreneurs to use Internet as a new medium to improve their business activities.

The study helps to inform the authority to plan and improve the Internet technology in Malaysia so that new systems are developed that have "ease of use" factor to optimize the usage of e-commerce among the enterprenurs. Government have invested a lot of money to develop systems that expedites the process and affairs related to enterpreneurship such as company registration, Finance Ministry's e-perunding

(https://eperunding.treasury.gov.my/v41/) and the GST (Goods and Sales Tax) system.

In this era, entrepreneurs should equip themselves with skills and knowledge of the latest technology since Internet enables the company to achieve its mission and objectives (Thomas Coney, 2012). Also, entrepreneurs should realise that they need to have staff that are competent and experience in using Internet. Couple with government incentives on innovations and investment on the infrastructures, business people especially women entrepreneurs should grab the opportunities of easy access of doing business not only in Malaysia but also internationally.

The government should invest more on the necessary infrastructure to make online business possible so as to encourage more young women entrepreneurs to involve themselves in Internet activities and other ICTs. Entrepreneurs should be given some form of incentives in developing their internal IT infrastructure, such as tax relief. In addition, training programmes on the use of IT infrastructure should be provided to the women entrepreneurs. They must be made to realise that the digital revolution has taken place and the involvement in Internet activities will definitely help the entrepreneurs in opening up opportunities for their business ventures. 


\section{References}

A. Jumaat, M. \& Jasmani, M. (2012). Factors That Encourage Women Involvement in SMEs in Pahang. The Journal of Human Resource and Adult Learning, Vol. 8 (2), 34-41.

Anon. (2008). Kesan penggunaan Internet kpd masyarakat. Harian Metro, 15 October

Cho, D. Kwon, H. \& Lee, H. (2007). Analysis of Trust in Internet and Mobile Commerce Adoption. System Sciences, Jan.

Davis. J.A. (1971). Elementarv Survey Analvsis. Englewood, NJ: Prentice-Hall.

Davis, F., Bagozzi, D. \& Warshaw, (1989). Perceived usefulness, perceived ease of use, and user acceptance of information technology. MIS Quarterly, 319-340.

Deamer, I., \& Earl, L. (2004). Searching for Entrepreneurship. Industrial and Commercial Training, Vol 36 (3), 99 103.

Eastin, M. S. \& LaRose, R. 2000. Internet Self-Efficacy and the Psychology of the Digital

Divide. Journal of Computer-Mediated Communication, retrieved 15 Februari, 2006

From http://onlinelibrary.wiley.com/doi/10.1111/i.1083-6101.2000.tb00110.x/full.

Emasria binti Ismail. 2006. Tahap Perlaksanaan Sistem E-Dagang Dalam Industri Pembinaan Di Malaysia. Kajian Ijazah Sarjana Muda Kejuruteraan, Fakulti Kejuruteraan Awam, Universiti Teknologi Malaysia.

Fan, Y., Saliba, E., Kendall, J. \& Newmarch, J. (2005). Speech interface: an enhancer to the acceptance of mcommerce application. Proceedings of the International Conference on Mobile Business (ICMB'05), Sydney, Australia.

Hamisah, H. (2002). Survey: Self-employment a rising Trend. Nation (Thailand), July 26, 2002.

Hornaday, J. A. (1982). Research about Living Entrepreneurs. N. J. Prentice Hall.

Jarvenpaa, S., Tractinsky, N. \& Vitale, M. (2000). Consumer trust in an Internet store: a cross-cultural validation. Information Technology and Management, Vol.1 (12), 45-71.

Klein, P. G., \& Cook, M. L. (2005). T. W. Schultz and the Human-Capital Approach to Entrepreneurship. Paper presented at the American Economics Association.

Kloping, I. M., \& McKiney, E. (2004). Extending the technology acceptance model and the task-technology fit model to consumer e-commerce. Information Technology, Learning, and Performance Journal, Vol. 22 (1), 35-48.

Lee, M. (2009). Factors influencing the adoption of Internet banking: An integration of TAM \& TPB with perceived risk \& perceived benefit. Electronic Commerce Research \& Applications, Vol. 8 (3), 130-141.

Lim, K. S., Lim, J. S., \& Heinrichs, J. (2008). Testing an integrated model of e-shopping website usage. Journal of Internet Commerce, Vol. 7 (3), 291-312.

Man, K. C. \& Waiman, C. (2001). Determinants of the intention to use Internet, retrieved 20

January, 2016 from http://www.sciencedirect.com/science/article

Maria Minniti (2009), Gender Issues in Entrepreneurship, Foundations and Trends $®$ in Entrepreneurship. Vol. 5 (7/8), 497-621.

Marshall, M., \& Oliver, W. (2005). The Effects of Human, Financial, and Social Capital on the Entrepreneurial Process for Entrepreneurs in Indiana. Allied Social Science Associations Annual Meeting. Philadelphia.

Martin, L. M. \& Wright, L. (2005). No gender in Cyberspace? Empowering Enterpreneurship and Innovation in Female-Run ICT Small Firms. Journal of Enterpreneurial Behaviour and Research, Vol. 11 (2). 162-178.

McCloskey, D. (2004). Evaluating electronic commerce acceptance with the technology acceptance model. Journal of Computer Information Systems, 49-57.

Normah, M., Wan Amizah, W., Fauziah, A., Maizatul, H. \& Mohd Helmi, A. (2013). Kebergantungan Internet Dan Aktiviti Online Remaja Di Lembah Kelang. Malaysian Journal of Communication, Vol. 29 (1): 199-212.

Norudin, M., Suzana, T. \& Siti Haryati (2008). Driving Force Motivation Amongst Muslim Women to venture in SMEs, Proceeding of International Conference on Islamic Entrepreneurship, N. Sembilan, Malaysia.

Nurwahida, F. \& Abdul Manaf, B. (2011). Malay Women Entrepreneurs in the Small and Medium Sized ICT-Related Business: A Study on Need for Achievement, International Journal of Business and Social Science, Vol. 2 (13), 272278. 
Sara, N. B. (2007). Factors Influencing The Adoption Of Internet Banking. Unpublished Master's Thesis, Department of Business Administration and Social Sciences, Lulea University of Technology.

Sekaran, U. (2003). Research Method for Business: A Skill Building Approach, 4th edition, John Wiley \& Sons.

Thomas, C. (2012). Entrepreneurship Skills for Growth-Orientated Businesses, Report for the

Workshop on 'Skills Development for SMEs and Entrepreneurship' in Copenhagen, retrieved 3 September, 2016 from www.oecd.org/cfe/leed/Cooney_entrepreneurship_skills_HGF.pdf

Van Gelderen, M. (2007). Research based yet action oriented: Developing individual level enterprising competencies. Proceeding 17th Global Conference - Internationalizing

Entrepreneurship Education and Training. Faculty of Management and Economics, Gdansk University of Technology. Gdansk: Poland, 8 - 11 July 2007.

Wei, T., Marthandan, G., Chong A. Y., Ooi, B., \& Arumugam, S. (2009). What drives Malaysian m-commerce adoption? An empirical analysis. Industrial Management \& Data Systems, Vol. 109 (3): 370-388.

Wendy, T. \& Siong-choy, C. (2008). Theorising a framework of factors influencing performance of women entrepreneurs in Malaysia, Communications of the IBIMA, Vol. 2 (5), 31-38.

Women are Owning More Small Businesses, retrieved 20 August, 2016 from http://www.theatlantic.com/business/archive/2015/04/women-are-owning-more-and-more-small-businesses

Yoon, S. J. \& Kim, J. (2001) The Effects of Perceived Consumer Characteristics on the Choice and Use of Internet Ads, Brand Management, Vol. 8 (4), 346-364.

Zafir, M., Mohd Hizam, H. \& Fazilah, M. (2013). Pengurusan Organisasi. Selangor: Cengage Learning Asia. 